\title{
The Influence of Firm's Characteristics on the Level of Intellectual Capital Disclosure of Indonesian Islamic Banking
}

\author{
Ihyaul Ulum*, Ahmad Waluya Jati, Mia Indri Audina, Adi Prasetyo \\ Accounting Department \\ University of Muhammadiyah Malang \\ Malang, Indonesia \\ *ihyaul@umm.ac.id,jati67@yahoo.com,miaudina08@gmail.com, adiprst4@gmail.com
}

\begin{abstract}
The purpose of this research is to analyze the effect of firm size, profitability, leverage, firm age, ownership of the company, and the type of Islamic banking for the intellectual capital disclosure. This research used 34 annual reports of Islamic Bank (IB) and Sharia Business Unit (SBU) registered to the Financial Services Authority in 2015. Samples were selected by purposive sampling method. This research used multiple linier regression analysis. The result showed that the type of Islamic banking affects the intellectual capital disclosure. IB has its own annual report so that the information disclosed is more than the SBU that the report contained in the annual report of a conventional bank.
\end{abstract}

Keywords: firm's characteristics, intellectual capital, intellectual capital disclosure, Islamic banking

\section{INTRODUCTION}

The last few decades, these companies are required to be able to meet the needs of users of information. The company strives to meet that by making the activities that occur within the company. Disclosure of the company can be divided into mandatory disclosure and voluntary disclosure. Much of the information that may be disclosed voluntarily, one of them is the intellectual capital. IC has played an increasingly important role in creating a sustainable competitive advantage for the company [1]. According to Ulum [2], intellectual capital disclosure in the annual report of the company has become an interesting theme, because intellectual capital is believed to be the driving factor and creator of enterprise value (value drivers $\&$ creation).

Mouritsen, Larsen [3] stated that IC disclosure in the financial statements as a way of disclosing that the report describes the credible, integrated (cohesive) as well as "true and fair" company activities. Bukh, Larsen [4] states that the IC report in practice contains financial and non-financial information as diverse as employee turnover, job satisfaction, in-service training, customer satisfaction, accuracy of supply, and so on.

The effect of firm's caracteristics on the level of intellectual capital disclosure has been proven empirically by Julindra and Susanto [5]. Firm's characteristic are projected by firm size, leverage, profitability, and listing age, the results indicated that all the independent variables are significantly affecting the intellectual capital disclosures. Suhardjanto and Wardhani [6] proved also that its characteristics can affect the performance of the companies listed in the Indonesia Stock Exchange. In addition, this study also proves information gap that still occur.

Indonesia's banking sector is growing rapidly and its presence is very important in the process of developing the country's economic. Sharia-based banking is also arising and growing rapidly along with the situation of Indonesia as a Moslem predominant nation. There are three types of Islamic banking in Indonesia, Islamic Banks (IB), Sharia Business Unit (SBU), and Sharia People Finance Bank (SPFB). Until July 2016, there were 12 institutions of Islamic banks in Indonesia. Meanwhile, commercial bank which has had a business unit of Sharia are 22 banks and there are 165 SPFB in Indonesia [7].

Based on the phenomena above, we are interested in studying the effect of the characteristics of companies consisting of company size, profitability, leverage, firm age, ownership of the company, and the type of Islamic banking on the intellectual capital disclosure of Islamic banking in Indonesia. The reason in selecting sharia-based banking sector is because, according to Firer and Williams [8], the banking industry is one of the most intensive sectors of its IC.

This research used the components of intellectual capital (IC) that are grouped into three categories consisting of 36 items in question consists of: 8 items of human capital; 15 items of structural capital; and 13 items of relational capital [9].

Brooking [10] stated that the IC is the term given to a combination of intangible assets of markets, intellectual property, employees, and infrastructure that enables enterprises to be able to function. This definition clearly implied that IC is not just about human resources/human capital. Human capital is only one component of IC. Table 1 summarizes some of the constructs and definitions of IC offered by scholars [11]: 
TABLE I. CONSTRUCTS AND DEFINITIONS OF IC

\begin{tabular}{|c|c|c|}
\hline Scholars & Constructs & Definition of IC \\
\hline [12] & $\begin{array}{lr}\text { Human } & \text { capital } \\
\text { Structural } & \text { capital } \\
\text { Relational capital }\end{array}$ & $\begin{array}{l}\text { IC may provide a new } \\
\text { resource-base for an } \\
\text { organization to compete and } \\
\text { win }\end{array}$ \\
\hline [13] & $\begin{array}{l}\text { Human capital } \\
\text { Structural capital }\end{array}$ & $\begin{array}{l}\text { IC is the sum of the "hidden" } \\
\text { assets of the company, such as } \\
\text { brands, trademarks and patents } \\
\text { and also includes all assets } \\
\text { that are not shown in the } \\
\text { financial statements. IC is a } \\
\text { company's the most important } \\
\text { source of sustainable } \\
\text { competitive advantages }\end{array}$ \\
\hline [14] & $\begin{array}{lr}\text { Human } & \text { capital } \\
\text { Structural capital } & \text { customer capital }\end{array}$ & $\begin{array}{l}\text { IC is knowledge, information, } \\
\text { intellectual property and } \\
\text { experience; it is a collective } \\
\text { brainpower or useful } \\
\text { knowledge }\end{array}$ \\
\hline [15] & $\begin{array}{lr}\text { Human } & \text { capital } \\
\text { Structural capital } \\
\text { Customer capital }\end{array}$ & $\begin{array}{l}\text { IC refers to the difference } \\
\text { between a company's market } \\
\text { value and book value }\end{array}$ \\
\hline [16] & $\begin{array}{l}\text { Personnel } \\
\text { competence Internal } \\
\text { structure External } \\
\text { structure }\end{array}$ & $\begin{array}{l}\text { IC is knowledge that can be } \\
\text { converted into value }\end{array}$ \\
\hline [17] & $\begin{array}{lr}\text { Human capital } \\
\text { Structural capital } \\
\text { Relational capital }\end{array}$ & $\begin{array}{l}\text { IC is the effective use of } \\
\text { knowledge as opposed to } \\
\text { information }\end{array}$ \\
\hline [18] & $\begin{array}{l}\text { Human resources } \\
\text { Organizational } \\
\text { resources } \\
\text { Relational resources }\end{array}$ & $\begin{array}{l}\text { IC is all intangible resources } \\
\text { that are available to an } \\
\text { organization, that give a } \\
\text { relative advantage, and which } \\
\text { in combination are able to } \\
\text { produce future benefits }\end{array}$ \\
\hline [19] & $\begin{array}{l}\text { Human capital } \\
\text { Organizational } \\
\text { capital Social } \\
\text { capital }\end{array}$ & $\begin{array}{l}\text { IC is the sum of all knowledge } \\
\text { that an organization is able to } \\
\text { leverage in the process of } \\
\text { conducting business to gain } \\
\text { competitive advantage }\end{array}$ \\
\hline
\end{tabular}

Source: Wang [20]

Bukh, Nielsen [21] identified that the life of companies typically used in previous studies as a proxy for the risk. From this perspective, it is expected that new companies with little experience will have more confidence in non-financial disclosures. White, Lee [22] found a significant relationship between age of firm and the breadth of IC disclosure in the annual report of the company. Recently, Ulum, Septerina [23] found that intellectual capital disclosure level enhance organizational governance.

Ownership in Islamic banking is divided into two, namely the ownership of State-Owned-Enterprises/Local-GovernmentOwned-Enterprises and non-State-Owned-Enterprises/nonLocal-Government-Owned-Enterprises. Islamic Bank Unit and Sharia Business Unit that is owned by the State-OwnedEnterprises/Local-Government-Owned-Enterprises will reveal its intellectual capital not only to customers, but also showing its accountability to the state and local levels so that the intellectual capital disclosed is higher than the Islamic banking that is not owned by the State-Owned-Enterprises/LocalGovernment-Owned-Enterprises. The work of Anggraini [24] indicated that the corporate social disclosure level is affected by the percentage of management ownership.
Based on the phenomena above, the objective of study is the examine of effect of the companies characteristics that consisting of company size, profitability, leverage, firm age, ownership of the company, and the type of Islamic banking on the intellectual capital disclosure of Islamic banking in Indonesia.

\section{METHODS}

This research is associative research with taking an object of Islamic banking listed in the Financial Services Authority (FSA). The data was obtained through the official website of Islamic banks and Islamic business unit in 2015 with technical documentation. Sampling was done by using purposive sampling method, the criteria used are: (1) Islamic Banking is not a SPFB (2) Islamic Banks and Sharia Business Units which provide financial report in 2015, (3) publishing its annual report in 2015, and (4) data can be accessed. Based on these criteria, a total sample of 34 companies were obtained.

TABLE II. OPERATIONAL DEFINITION AND MEASUREMENT OF VARIABLES

\begin{tabular}{|c|c|c|c|}
\hline No & Variable & Definition & Measurement \\
\hline 1 & $\begin{array}{l}\text { Independent: } \\
\text { Firm Size }\end{array}$ & $\begin{array}{l}\text { Total assets as a proxy } \\
\text { for the company size }\end{array}$ & Size $=$ Total asset \\
\hline 2 & $\begin{array}{l}\text { Independent: } \\
\text { Profitability }\end{array}$ & $\begin{array}{l}\text { Basic of return on } \\
\text { assets level }\end{array}$ & $\begin{array}{l}\text { ROA }=\text { Net profit } \\
\text { after tax / total assets }\end{array}$ \\
\hline 3 & $\begin{array}{l}\text { Independent: } \\
\text { Leverage }\end{array}$ & $\begin{array}{l}\text { Amounts of money that } \\
\text { insured against debt }\end{array}$ & $\begin{array}{l}\text { DER = Total } \\
\text { liabilities / equity }\end{array}$ \\
\hline 4 & $\begin{array}{l}\text { Independent: } \\
\text { Firm Age }\end{array}$ & $\begin{array}{l}\text { Age of the company } \\
\text { since registered until } \\
\text { December } 31,2015\end{array}$ & $\begin{array}{l}\text { Age of enterprise }= \\
\text { December 2015 - } \\
\text { (month Year) the } \\
\text { registered companies }\end{array}$ \\
\hline 5 & $\begin{array}{l}\text { Independent: } \\
\text { Ownership of } \\
\text { the Company }\end{array}$ & $\begin{array}{l}\text { Ownership of State } \\
\text { owned enterprises / } \\
\text { local government } \\
\text { owned enterprises and } \\
\text { not State owned } \\
\text { enterprises / local } \\
\text { government } \\
\text { enterprises }\end{array}$ & $\begin{array}{l}0=\text { Ownership of } \\
\text { State owned } \\
\text { enterprises / local } \\
\text { government owned } \\
\text { enterprises } \\
1=\text { Ownership not } \\
\begin{array}{l}\text { State owned } \\
\text { enterprises / local } \\
\text { government owned } \\
\text { enterprises }\end{array}\end{array}$ \\
\hline 6 & $\begin{array}{l}\text { Independent: } \\
\text { the type of } \\
\text { Islamic } \\
\text { Banking }\end{array}$ & $\begin{array}{l}\text { Islamic Banks and } \\
\text { Sharia Business Unit }\end{array}$ & $\begin{array}{l}0=\text { Islamic Banks } \\
1=\text { Syariah Business } \\
\text { Unit }\end{array}$ \\
\hline 7 & $\begin{array}{l}\text { Dependent: } \\
\text { Intellectual } \\
\text { Capital } \\
\text { Disclosure }\end{array}$ & $\begin{array}{l}\text { Total disclosure of } \\
\text { information about the } \\
\text { IC that is presented in } \\
\text { the company's annual } \\
\text { report }\end{array}$ & $\begin{array}{l}\text { ICD-In constucted } \\
\text { by Ulum [25] }\end{array}$ \\
\hline
\end{tabular}

Multiple regression is used to perform data analysis based on the SPSS application. Content Analysis. Content analysis was conducted to identify the intellectual capital disclosures (ICD) at the company's annual report. ICD is the amount of disclosure of information about the IC that is presented in the company's annual report. IC information disclosure in the annual report is weighted according to the projections. Numeric codes used are as follows [26]:

$$
\begin{aligned}
& 0=\text { item are not disclosed } \\
& 1=\text { item disclosed in narrative form }
\end{aligned}
$$




\section{$2=$ item disclosed in numerical form \\ $3=$ item disclosed in monetary value}

\section{RESULTS}

Content analysis was done using four-way numerical coding system which developed by Guthrie, Petty [27] to identify the intellectual capital disclosures (ICD) in the annual report of company. Four-way numerical coding system not only identify the quantity of disclosure, but also analyze the quality of disclosure.

The result indicate that there are $58 \%$ of the intellectual capital information not disclosed in 2015 (score $=0$ ). Intellectual capital information disclosed in 2015 was $42 \%$ which consisted of the disclosure in narrative form by $35 \%$, in the form of numeric disclosures by $4 \%$, and disclosure in monetary terms amounted to $3 \%$. The percentage of intellectual capital (IC) which is not disclosed considerably high. There are four items that were not disclosed by all companies, namely: patents, copyrights, trademarks and franchise agreements.

TABLE III. SuMmary OF RESUlts OF MULTIPLE REGRESSION ANALYSIS

\begin{tabular}{|l|l|l|l|}
\hline \multicolumn{1}{|c|}{ Variable } & \multicolumn{1}{|c|}{ Coeffisient } & $\begin{array}{c}\text { Standardized } \\
\text { Coeffisient }\end{array}$ & \multicolumn{1}{c|}{ Sig. } \\
\hline Constants & 26,946 & & 0,471 \\
\hline Firm Size & 2,966 & 0,214 & 0,246 \\
\hline Profitability & 1,070 & 0,224 & 0,123 \\
\hline Leverage & $-0,224$ & $-0,074$ & 0,587 \\
\hline Firm Age & $-0,538$ & $-0,117$ & 0,449 \\
\hline Ownership of the Company & $-2,539$ & $-0,067$ & 0,645 \\
\hline The type of Islamic banking & $-25,675$ & $-0,658$ & 0,001 \\
\hline Fstatistic $=6,238$, Sig. $=0,000$ & \\
\hline R-squared $=0,581$, Adj. R-squared $=0,488$ \\
\hline
\end{tabular}

Test results of determination coefficient can be obtained the results of Adjusted R Square as 0.488 . These results show that the variation of variables company size, profitability, leverage, firm age, ownership of the company, and the type of Islamic banking on the disclosure of intellectual capital (ICD) amounted to $48.8 \%$ while the remaining $51.2 \%$ is contributed by other variables not discussed in this research.

The result of partial significance (statistical test $t$ ) can be determined that the partial effect of independent variables consisting of company size, profitability, leverage, firm age, ownership of the company, and the type of Islamic banking on the dependent variable of intellectual capital disclosure (ICD) is shown as follows:

Firm size generates tcount at 1,186 and the Sig. 0,246. The test results obtained by the Sig. $>0.05$ indicated that firm size has no significant effect on the intellectual capital disclosure (ICD). The results are consistent compared to the research by Nugroho [28], but not in line with the research of Suhardjanto and Wardhani [6], Oktavianti [29], and Julindra and Susanto [5]. The size of the total assets of Islamic banking did not affect the disclosure of intellectual capital. It may be due to Islamic banking maintain its competitive advantage that has been held, thus reduced the disclosure as an attempt not to be imitated by competitors.
Profitability generates values tcount 1,590 and the Sig. 0,123 . The test results obtained by the Sig. $>0.05$ indicated that profitability has no significant effect on the intellectual capital disclosure (ICD). The results of this study are not consistent with the research of Suhardjanto and Wardhani [6], Oktavianti [29], and Julindra and Susanto [5] which affect the profitability of the disclosure of intellectual capital. This could be because when the profitability of Islamic banking is growing and financial capabilities are rising but are not used to fund the disclosure of intellectual information and may be used for other purposes.

Leverage generate value tcount at -0.549 and the Sig. 0,587 . The test results obtained by the Sig. $>0.05$ indicated that leverage has no significant effect on the intellectual capital disclosure (ICD). The results are consistent with the research of Suhardjanto and Wardhani [6], Nugroho [28], Ramananda and Widi [30], and Oktavianti [29]. This can be due to Islamic banking with a high degree of leverage that is not in line with the intellectual capital that is exposed. It is because the company wants to maintain the image, good name and reputation of the company that are not optimal in the management of the leverage ratio, so that those are not widely known by external parties.

Firm age generate value tcount at -0.769 and the Sig. 0,449 . The test results obtained by the Sig. $>0.05$ indicated that firm age has no significant effect on the intellectual capital disclosure (ICD). The results are consistent with the research of Suhardjanto and Wardhani [6], Nugroho [28], and Oktavianti [29] This could be due to the high age Islamic banking does not always mean the experience and understanding of the intellectual capital disclosure is better, also the newly established Islamic banking but owned by commercial banks, which had stood for a long time could affect the disclosure of intellectual capital of Islamic banks and Islamic unit.

Ownership of the Company produce value tcount at -0.465 and the Sig. 0,645. The test results obtained by the Sig. $>0.05$ indicated that ownership of the company has no significant effect on the intellectual capital disclosure (ICD).This study results prove that not all Islamic banking which is owned by the state owned enterprises / local government owned enterprises reveal much information about intellectual capital and intellectual capital information as a responsibility to the country or region. The results of the study mean that not all Islamic banking that is not owned by the state owned enterprises/local government owned enterprises revealed little information about intellectual capital. It is because the state owned enterprises/local government enterprises are likely to have valuable resources and rarely disclosed those in the annual report as competitive advantage that they have in order to be able to create additional values for the company that does not own Islamic banking that.

The type of Islamic banking produces a value as much as 3.640 tcount and the Sig. 0,001. The test results obtained by the Sig. $<0.05$ indicated that the type of Islamic banking have a significant effect on the intellectual capital disclosure (ICD). These research results indicated an average of Islamic Banks disclosed more information intellectual capital, that is $66.9 \%$ higher than the Islamic business unit, which only scored 
39.4\%. This is because the Islamic Banks (IB) has its own annual report so that any information can be disclosed including intellectual capital as much as possible. RBT theory based on valuable, rare, inimitable resource of company, and there is no replacement resources that will be disclosed by the company to create a competitive advantage.

Stakeholder theory based on the management should conduct and report the activities that occur within the company to their stakeholders that are appropriate or exceed the expectations of stakeholders. While the annual report of Sharia Business Unit (SBU) is contained in the consolidated annual report of conventional commercial bank. It is because it is a business unit of the conventional commercial bank, so that there will be not too much disclosure because the annual report contains more information about Sharia Business Unit and a little information about Sharia Business Unit. Therefore, it cannot report any activity beyond what is expected by stakeholders, the possibility occurs is the activity disclosed to be more conventional commercial bank activity in general.

The results of simultaneous significance test (the test statistic F) can be obtained F-count as much as 6.238 and a significant value as 0.000 . The test results obtained by the Sig. $<0.05$ indicated that the test results obtained by the Sig. $<0.05$ indicated that the regression model in this study is true.

\section{CONCLUSION}

The awareness of Islamic banking upon the intellectual capital disclosure (ICD) is low, where there are half of the items were not disclosed by the Islamic banking and there are four items that are not disclosed in the annual report of every Islamic bank. Islamic banks are revealing intellectual capital more compared to Islamic business units.

Furthermore, after the hypothesis test in this study indicated that company size, profitability, leverage, firm age, and ownership of the company does not have a significant effect on the intellectual capital disclosure. Yet, types of Islamic bank has a significant effect on the intellectual capital disclosure (ICD). F Statistical test results showed that the regression model in this study is true.

\section{REFERENCES}

[1] R. S. Kaplan and D. P. Norton. "Strategy maps: Converting intangible assets into tangible outcomes": Harvard Business Press; 2004.

[2] I. Ulum. "Analisis Praktek Pengungkapan Informasi Intellectual Capital dalam Laporan Tahunan Perusahaan Telekomunikasi di Indonesia". Jurnal Reviu Akuntansi dan Keuangan (JRAK). 2011;1(1):49-56.

[3] J. Mouritsen, H. T. Larsen and P. Bukh. "Intellectual capital and the 'capable firm': narrating, visualising and numbering for managing knowledge". Accounting, organizations and society. 2001;26(7):735-62.

[4] P. N. Bukh, H. T. Larsen and J. Mouritsen. "Constructing intellectual capital statements". Scandinavian journal of management. 2001;17(1):87-108.

[5] K. Julindra and L. Susanto. "Analisis Pengaruh Ukuran Perusahaan, Leverage, Profitabilitas, Dan Umur Listing Terhadap Pengungkapan Modal Intelektual Pada Perusahaan Manufaktur Yang Terdaftar Di Bursa Efek Indonesia (BEI) Pada Tahun 2012-2014". Jurnal Ekonomi. 2015; XX(01):103-19.

[6] D. Suhardjanto and M. Wardhani. "Praktik intellectual capital disclosure perusahaan yang terdaftar di bursa efek Indonesia". JAAI. 2010;14(1):71-85.
[7] Statistik Perbankan Syariah, 14 (2016).

[8] S. Firer and S. M. Williams. "Intellectual capital and traditional measures of corporate performance". Journal of intellectual capital. 2003;4(3):348-60

[9] I. Ulum. "Intellectual Capital: Model Pengukuran, Framework Pengungkapan, dan Kinerja Organisasi". Malang: UMM Press; 2015.

[10] A. Brooking. "Intellectual Capital: Core Assets for the Third Millennium". London: Enterprise Thomson Business Press; 1996.

[11] I. Ulum, I. Ghozali and A. Purwanto. "Intellectual Capital Performance of Indonesian Banking Sector: A Modified VAIC (M-VAIC) Perspective". Asian Journal of Finance \& Accounting. 2014;6(6):10323.

[12] N. Bontis. "Intellectual capital: an exploratory study that develops measures and models". Management Decision. 1998;36(2):63-76.

[13] J. Roos, G. Roos, N. C. Dragonetti and L. Edvinsson. "Intellectual Capital: Navigating in the New Business Landscape". Houndsmills: Macmillan Business; 1997.

[14] T. A. Stewart. "Intellectual Capital". London: Nicholas Brealey Publishing; 1997.

[15] L. Edvinsson and M. S. Malone. "Intellectual Capital: Realizing Your Company's True Value by Finding Its Hidden Brainpower". New York: HarperCollins; 1997.

[16] K. E. Sveiby. "Intellectual capital: thinking ahead". Australian CPA. 1998;68(2):18-22.

[17] N. Bontis. "Managing organizational knowledge by diagnosing intellectual capital: framing and advancing the state of the field". International Journal of Technology Management. $1999 ; 18(5 / 6 / 7 / 8): 433-62$.

[18] D. Andriessen and C. Stam. Intellectual capital of the European Union: measuring the Lisbon agenda. HOLLAND University of professional education, de Baak-Management Centre VNO-NCW: Centre for Research in Intellectual Capital. 2004.

[19] M. A. Youndt, M. Subramaniam and S. A. J. J. o. M. s. Snell. "Intellectual capital profiles: An examination of investments and returns". 2004;41(2):335-61.

[20] J. C. Wang. "Investigating market value and intellectual capital for S\&P 500". Journal of Intellectual Capital. 2008;9(4):546-63.

[21] P. N. Bukh, C. Nielsen, P. Gormsen and J. Mouritsen. "Disclosure of information on intellectual capital in Danish IPO prospectuses". Accounting, Auditing \& Accountability Journal. 2005;18(6):713-32.

[22] G. White, A. Lee and G. Tower. "Drivers of voluntary intellectual capital disclosure in listed biotechnology companies". Journal of Intellectual Capital. 2007;8(3):517-37.

[23] I. Ulum, A. T. Septerina, A. Prasetyo, N. Mohamed and A. Abdullah. "Does Intellectual Capital Disclosure Enhance Organization Governance? Evidence from Indonesian Biggest Organizations". Advanced Science Letters. 2017;23(8):7878-81.

[24] F. R. R. Anggraini. "Pengungkapan informasi sosial dan faktor-faktor yang mempengaruhi pengungkapan informasi sosial dalam laporan keuangan tahunan (Studi empiris pada perusahaan-perusahaan yang terdaftar bursa efek Jakarta)". Simposium Nasional Akuntansi. 2006;9:23-6.

[25] I. Ulum. "Intellectual capital disclosure: Suatu analisis dengan four way numerical coding system". Jurnal Akuntansi \& Auditing Indonesia. 2015;19(1):39-50.

[26] I. Ulum. Peran Pengungkapan Modal Intelektual dan Profitabilitas dalam Hubungan antara Kinerja Modal Intelektual dengan Kapitalisasi Pasar [Disertasi Tidak Dipublikasikan]. Semarang: Universitas Diponegoro; 2015.

[27] J. Guthrie, R. Petty, F. Ferrier and R. Wells, editors. There is no accounting for intellectual capital in Australia: a review of annual reporting practices and the internal measurement of intangibles. OECD Symposium on Measuring and Reporting of Intellectual Capital, Amsterdam; 1999.

[28] A. Nugroho. "Faktor-Faktor Yang Mempengaruhi Intellectual Capital Disclosure (ICD)". Accounting Analysis Journal. 2012;1(2). 
(Perbandingan antara Perusahaan Perbankan di Indonesia dan

[29] H. Oktavianti. "Faktor-Faktor Yang Mempengaruhi Intellectual Capital Disclosure (ICD)". Accounting Analysis Journal. 2014;3.

[30] D. Ramananda and N. Y. Widi. "Analisis Pengungkapan Intellectual Thailand)". Dinamika Akuntansi Keuangan dan Perbankan. 2014;3(1). 